DEPARTMENT OF ECONOMICS

WORKING PAPERS 18

JAANA RAHKO

\title{
Market Value of R\&D, Patents, and Organizational Capital: Finnish Evidence
}


ISBN 978-952-476-451-3 (print)

ISBN 978-952-476-452-0 (online) 


\title{
Table of contents
}

Abstract 1

1. Introduction $r$

2. Intangible assets and the market value equation $\quad 5$

2.1. The market value approach $\quad 5$

2.2. Estimation $\quad 9$

3. Data and descriptive statistics $r$

3.1. Data sources 10

3.2. Variables 11

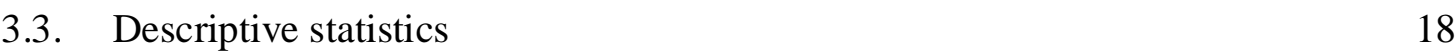

$\begin{array}{ll}\text { 4. Results } & 24\end{array}$

5. Conclusions $\quad 31$

$\begin{array}{ll}\text { References } & 33\end{array}$

Appendix 1. Sample firms $\quad 36$

Appendix 2. Estimating the organizational investments 37

Appendix 3. Sample selection model 39

\begin{abstract}
Rahko, Jaana (2013). Market Value of R\&D, Patents, and Organizational Capital: Finnish Evidence. University of Vaasa, Department of Economics Working Papers 18, 40 p.

This paper studies how organizational assets, R\&D, and patents affect the market valuation of Finnish firms. The occupational information from Finnish linked employer-employee data is used to form estimates of firms' organizational investments. These estimates are accompanied by data on firms' R\&D investments, patent applications, and patent citations. A non-linear least squares regression and a panel regression are run to investigate their contribution to the market valuation of Finnish firms during the period 1995-2008. The results indicate that organizational capital, $R \& D$, patent citations and, to some extent, the patent stock have a positive and significant effect on the market value. Furthermore, the results show that the omission of organizational activities leads to significant downward bias in the importance of R\&D and patent activities.
\end{abstract}

JEL classification: O30, O34, M12, G32

Keywords: organizational capital, R\&D, patents, intangible assets, market value 


\section{Introduction}

The performance of firms has become increasingly dependent on knowledge and other intangible assets. These assets include, for example, research and development (R\&D), patents, brands, customer relationships, software, and organizational capital. Despite their importance, intangible assets are not fully considered in our current accounting system and we have few systematic ways to value them. These intangibles are one likely reason why we so often observe that the publicly listed firms have much higher market values than their book values would suggest. We will examine the relationship between intangibles and firm performance by studying the effect of organizational capital, patents, and R\&D on firms' market valuation using data on publicly listed Finnish firms. This paper contributes to the current literature by using Finnish linked employer-employee data (LEED) to measure organizational investments and combining this dataset with data on patents and firmreported $R \& D$ expenditures.

Data on patents and R\&D expenditures and their effect on the firm's market value have been studied for a long time (for example by Griliches (1981), Megna and Klock (1993), Chan et al. (2001), and Hall et al. (2007)). These studies are often concentrated in the manufacturing sector because non-manufacturing firms are not as often engaged in R\&D or patenting activities. However, these firms can be very active in other types of intangible capital production, such as building brands and organizational competence. Furthermore, organizational and marketing competences have become increasingly important in all industries, and therefore, it is essential to be able to evaluate their contribution to firm performance. Organizational investments and firm's market value have not been studied as extensively as $R \& D$, but the few existing studies, for example 
Brynjolfsson et al. (2002), Lev and Radhakrishnan (2003), Hulten and Hao (2008), and Piekkola (2013), find that organizational investments contribute significantly to the market value. Piekkola (2013) has studied the market value of intangible investments in Finnish listed firms using LEED-based data; however, the patent variables or firm-reported R\&D expenditure data were not included. Patent variables are also absent from the other abovementioned studies. The present study contributes to the literature by including these variables as well as organizational investments.

The empirical part of this paper uses the information on firms' employee composition and compensation provided in LEED to construct estimates of firms' organizational capital. Organizational and marketing capital includes brands, firm-specific human capital and the efficiency of organizational structures, such as the competence of managers and human resource workers. Management work, hiring consultants, educating the employees, and marketing and sales expenditures aim for long-lasting improvements in the firm performance and should therefore be considered as an investment. We will estimate a firm's organizational and marketing investments by using the number of managers and marketing personnel in the firm and their wages. This expenditure-based approach developed by Görzig et al. (2010) (later GPR) is analogous to country-level estimates presented previously by Corrado et al. (2005). Here, the focus is on the firm's own account production of organizational capital. The approach uses the employees' wages and the cost structure of consulting and market research services available in the economy to estimate the capital and intermediate costs that are also associated with organizational and marketing investments (GPR 2010).

Research and development expenditures are an input of innovation activity and investments that also aim to improve firm performance in the future. At the output side of 
innovation activities are patent applications. A granted patent gives its holder monopoly power, facilitates the sales of technology, and offers protection in infringement cases. Patents and accumulated $R \& D$ are valuable assets and therefore should contribute to a firm's market value. Nevertheless, patent-based measures have some limitations because not all inventions are patentable, and patents are not the only way to utilize inventions. Furthermore, the value distribution of patents is highly skewed. Some patents are highly valuable, whereas others have no commercial application at all. Because these properties depend to a large extent on the industry, it is clear that different industries can have very different propensities to patent (Czarnitzki et al. 2006; Levin et al. 1987). To mitigate the above-mentioned problems, the analysis in this paper will include forward patent citations to control for the quality of a firm's patent stock, as has been done in previous studies (Hall et al. 2005; Harhoff et al. 1999; Trajtenberg 1990).

In this study, we will use Tobin's q as a measure of a firm's market valuation (Griliches 1981; Hall et al. 2007). A firm's market value is the value that the financial markets place on the firm's tangible and intangible assets. If we assume that capital markets are efficient, the market value should also be equal to the present value of discounted future payouts and, hence, be closely related to the future profits. $R \& D$ and organizational investments should increase firm productivity and profitability over a longer time period but the time lag may be difficult to predict (Griliches 1981; Hall et al. 2007). The market value is a forward-looking measure of firm performance and should capture the increase in future profitability without a lag. Hence, we should observe a positive association between the intangible capital and a firm's market value. 
The remainder of this paper is organized as follows. The next section presents the econometric methods. The third section describes the data and the main variables, the fourth section presents the empirical results, and the fifth section concludes the paper.

\section{Intangible assets and the market value equation}

\subsection{The market value approach}

This section presents the market value model, which has been frequently used to study the value of intangible assets. We want to study the effect of intangible capital on firm performance, which we can do by studying the market value or alternatively by studying the firm's profits or total factor productivity. A profit- or productivity-based analysis has its advantages but in the context of intangible assets, such analyses also have some weaknesses. $R \& D$ as well as organizational investments aim to increase the firm productivity in the future and over a long time period, but this time lag may be long and uncertain (Griliches 1981; Hall et al. 2007). Furthermore, measuring the returns to investments in intangibles requires careful attention to the timing and measurement of other inputs, which in itself may be intangible (Hall 2000). The market value approach, however, enables a forward-looking evaluation of firm performance and avoids the problem with the timing of productivity effects. ${ }^{1}$

The market value model was initially introduced by Griliches (1981) to analyze the economic value of $R \& D$ and patents. In this model, the firm is considered to be a bundle of assets. These assets can include tangible capital, such as plants and equipment, knowledge

1 For results on the productivity effects of patents, see Bloom and Van Reenen (2002). For results on other intangible assets and productivity, see Ilmakunnas and Piekkola (2010), who use a LEEDbased measurement of intangibles. 
assets, such as patents and $\mathrm{R} \& \mathrm{D}$, brands, customer relationships, software, and organizational competence. The aim is to measure the effect of each of those assets on the market value, which makes this approach comparable to hedonic price models. The model relies on the assumption that financial markets are efficient and that the market value equals the present value of discounted future dividends. It is well known that anomalies occur in financial markets and that investors are not always rational. Thus, our market value model should be applied with these limitations in mind.

Because the general functional form of the value function for an intertemporal maximization program with many asset types is difficult to derive, we will follow the literature and assume that a firm's assets enter the market value equation additively. We will apply the model used by Hall et al. (2005) and extend it by including organizational capital. The method to include the organizational capital is similar to how the accumulated R\&D investments are included. An alternative approach to incorporate organizational capital into the model would be through the valuation coefficient $\mathrm{q}_{\text {it }}$ because it reflects a firm's monopoly power and market structures (Griliches 1981). Organizational capital is clearly an instrument for building monopoly power and affecting market structures but we want to treat all intangible investments symmetrically (Hall and Oriani (2006); Sandner and Block (2011)) and hence adopt the first approach. We can write the market value equation as follows:

$$
V_{i t}=q_{i t}\left(K_{i t}+\gamma_{R \& D} R \& D_{i t}+\gamma_{O C} O C_{i t}\right)^{\sigma}
$$

and

$$
q_{i t}=\exp \left(y_{t}+m_{k}+u_{i t}\right)
$$


In equation $1, V_{i t}$ is the market value of the firm $i$ at time $t$, and $K_{i t}$ is the tangible assets of the firm. The organizational and $R \& D$ assets are represented by $O_{i t}$ and $R \& D_{i t}$, respectively. The current valuation coefficient $\mathrm{q}_{i t}$ includes year $\left(\mathrm{y}_{\mathrm{t}}\right)$ and industry $\left(\mathrm{m}_{\mathrm{k}}\right)$ effects as well as individual disturbance $\left(\mathrm{u}_{\mathrm{it}}\right)$. We could also model the valuation coefficient to capture other factors that affect the valuation multiplicatively. $\sigma$ measures the returns to scale. When $\sigma=1$, there are constant returns to scale, and $\gamma_{R \& D}$ and $\gamma_{O C}$ are the shadow values of the ratios of $R \& D$ assets to tangible assets and organizational assets to tangible assets, respectively (Hall and Oriani 2006). The shadow values show the contribution of intangible capital to the firm's market value when the firm spends one additional unit on intangible capital. The shadow values are an equilibrium outcome in the financial markets reflecting firms' investments and investors' expectations of future cash flows, and the shadow values should not be given a structural interpretation. Furthermore, the shadow values are also not necessarily constant over time, although for convenience, we will not allow them to vary in our analysis.

Next, after taking the logarithm of equation 1 and subtracting the logarithm of $\mathrm{K}_{\mathrm{it}}$ from both sides, we can write the equation as

$$
\log \frac{V_{i t}}{K_{i t}}=\log q_{i t}+(\sigma-1) \log K_{i t}+\sigma \log \left(1+\gamma_{R \& D} \frac{R \& D_{i t}}{K_{i t}}+\gamma_{O C} \frac{O C_{i t}}{K_{i t}}\right)
$$

Equation 2 includes the log of Tobin's q on the left-hand side and the total physical assets and intangible capital intensities with respect to total assets on the right-hand side. The next step is to modify the model to include patents and patent citations following the example of Hall et al. (2005) and Hall et al. (2007). This formulation includes patent applications as an 
output and quality indicator of the R\&D stock and the patent citations as a quality indicator of the patent stock. The estimable equation is given by

$$
\begin{aligned}
& \log \frac{V_{i t}}{K_{i t}}=\log q_{i t}+(\sigma-1) \log K_{i t} \\
& +\sigma \log \left(1+\gamma_{R \& D} \frac{R \& D_{i t}}{K_{i t}}+\gamma_{P A T} \frac{P A T_{i t}}{R \& D_{i t}}+\gamma_{C I T} \frac{C I T_{i t}}{P A T_{i t}}+\gamma_{O C} \frac{O C_{i t}}{K_{i t}}\right)+\varepsilon_{i t}
\end{aligned}
$$

The equation is extended with a set of control variables, which enter through the current valuation coefficient. We include year dummies to control for possible time trends and 12 industry dummies to control for industry-specific heterogeneity as well as dummies for no R\&D and no patents. Some listed firms have reported zero R\&D investments or applied for no patents, in which case the patent-intensity and citation-intensity variables are coded as zero. Firms that have chosen not to report their R\&D expenditures are dropped from the sample. Furthermore, the no patent dummy is included because if we observe that a firm has no patent applications, it does not follow that the firm has not made any inventions (Sandner and Block 2011). The innovations in some industries may not meet the patentability requirements, and some firms may choose not to patent their inventions. These firms may find it more profitable to utilize their innovations through trade secrecy or lead time. Observing no patents may therefore be a result of a strategic decision or an industry characteristic.

The firms are categorized into industry classes using Standard Industrial Classification (SIC) codes at their one-digit level except for software and manufacturing industries, where greater detail was needed. This approach results in 12 industry categories, such as electronics, paper industry, software, trade, and services. The industry classes and their characteristics are presented in Table 3. 


\subsection{Estimation}

In the early literature, equation (4) was typically simplified with a logarithmic approximation. The approximation would lead to a simple estimation and analysis, but the approximation is not preferable because it becomes inaccurate as the ratio of intangible assets to total assets grows. Table 1 below shows that the intangible assets make up a notable share of capital also in the Finnish firms. Therefore, the equation should be estimated using non-linear least squares estimation (NLS). Because the model is non-linear, the estimated coefficients cannot be compared in a straightforward manner. Therefore, in addition to the coefficients, it is necessary to calculate the elasticity of Tobin's q with respect to the regressors. The elasticities facilitate the interpretation of the coefficients also because the variables are measured in different units.

NLS estimation does not consider the unobserved firm-specific heterogeneity. However, a part of the heterogeneity is accounted for by using industry and year controls. For robustness, we also estimate the model by using OLS and panel models to test the importance of firm-specific effects. The non-linear least squares estimation is nevertheless the preferred estimation strategy because the firms' tangible and intangible capital stocks are part of a long-term strategy and change only slowly over time. In this case, the intangible capital intensities are likely to be highly correlated with firm-specific effects (Hall et al. 2005). Moreover, the main aim of the study is to examine the impact of intangibles across firms, thus justifying the pooled regression.

Another problem for the estimation is that reporting the R\&D expenditures is not compulsory, and there are many firms who choose not to report their R\&D investments. Reporting $R \& D$ is therefore an endogenous variable, which may cause a sample selection 
bias. Furthermore, some of the firms that report $R \& D$ expenses do so with interruptions and their R\&D histories are fragmented. Hall and Oriani (2006) and Toivanen et al. (2002) discuss the issue of sample selection more closely and conclude that it does not appear to form a significant bias. As a robustness check, we also account for the sample selection by estimating the model with the Heckman two-step estimator, where the first step is a probit estimation on whether the firm reports $R \& D$. The second step is to estimate the market value model including the inverse Mill's ratio as an explanatory variable. The results are reported in the appendix and show that the coefficient of the inverse Mill's ratio is not significant and the choice of $R \& D$ reporting does not appear to cause bias to the results.

\section{Data and descriptive statistics}

\subsection{Data sources}

The empirical analysis in this paper is based on market value, patent, and balance sheet data. The estimates of organizational capital stock are computed using the Finnish linked employer-employee data (LEED), which is obtained from the Confederation of Finnish Industries. LEED covers 8.3 million person-year observations and over 56 thousand firmyear observations for the 1995-2008 period. The data include a rich set of variables covering compensation, education, and occupation in the business sector. The occupational classification is specific to the data from the Confederation of Finnish Industries, and the classification is available for all employees in the firms considered here.

The R\&D expenditure, consolidated balance sheet, and market value data come from Thomson Reuters Worldscope. The variables used here are firm's total assets, R\&D 
expenditure, total debt, sales, and market value, which are measured at the end of each year. The financial variables have been deflated to real 2000 prices using the Ameco database.

Patent and citation data are formed using the EPO PATSTAT database. In this study, the analysis includes the firm's patent applications to the European Patent Office (EPO). EPO patents are a good indicator for R\&D quality because they are found to be more valuable than national patents (Deng 2007). Our patent variable includes all patent applications, although only granted patents could be used as well. The use of patent applications is supported by the fact that the information about the applications is made available more quickly. The use of EPO patent applications is also eased by the databases that the OECD maintains. The OECD Citations database contains information on all European patent applications and the citations these applications receive during the search in the patent office.

Despite using patent applications to the EPO, the value distribution of patents is highly skewed. The literature has typically used forward patent citation counts to control for patent quality. Our measure of citation counts includes all forward citations that the EPO patents receive within 3 years after the applications are published.

\subsection{Variables}

The dependent variable in the market value equation is the natural logarithm of Tobin's q. Tobin's q is defined as the ratio of a firm's market value to its book value. The book value of the firm is the total value of its assets reported on the balance sheet. The market value is the stock market value of the firm at the end of the year plus the market value of its debt. The market value of a firm's debt is difficult to obtain and therefore we follow the previous 
literature and use the nominal value of long-term and short-term debt instead (Hall et al. 2007).

Organizational competence and marketing activities are important determinants of firm performance. Management work and hiring consultants are expenditures that aim at establishing efficient organizational structures, strategies, and working methods in the firm. Firm-specific human capital can be created, for example, by educating the employees, whereas marketing and sales expenditures create and strengthen a firm's brands and customer relationships. Educating employees, hiring managers, or building up brands are costly activities from which the rewards materialize over a long time period. These expenditures reduce a firm's current profits in order to increase the value of the firm and its profits in the future in a similar way as investments in tangible capital. Therefore, expenditure on intangible assets should qualify as an investment and receive the same treatment as tangible investments (Corrado et al. 2005; Corrado et al. 2009; Görzig et al. 2010). The lack of visibility and verifiability of intangible assets explains why these investments are often difficult to measure and why they usually do not enter the official balance sheets. We follow the approach of GPR (2010) and use the linked employeremployee data to estimate the intangible investment within the firm.

Our estimate of organizational investments includes both marketing and management investments. The linked employer-employee data include information on employees' occupation and wages. By assuming that $20 \%$ of the marketing and management personnel's work goes into forming intangible assets, we can use their wage costs to estimate the organizational investment within the firm (Corrado et al. 2005; Corrado et al. 2009; Görzig et al. 2010). In addition to the wage costs, we also evaluate the capital and intermediate costs that are related to the intangible investments. These 
additional costs are estimated based on the cost structure of consultancy and business service firms (Nace 74) that produce organizational and marketing services in the market. The methodology to estimate the organizational investments is elaborated further in Appendix 2 and in GPR (2010).

The final organizational investment data have a few short gaps because of data issues. However, counting the organizational capital stock requires uninterrupted investment data series, and hence the missing observations are treated with interpolation, when the gap in the investment data is not longer than 3 years. In addition to the interpolation over gaps, no other correction measures are conducted. Once the organizational investments have been estimated, we can form the organizational capital stocks. Because the employer-employee data are not available for a long time period, the initial capital stocks must also be estimated. The starting values at the beginning of the observation period are estimated by using the investments in the first observation year. The formula for initial capital stock is shown below.

$$
O C_{i 0}^{\text {stock }}=\frac{O C_{i 0}^{\text {invest }}}{\delta+g}
$$

In estimating the initial capital stock, we assume a constant depreciation rate $(\delta)$ and a constant investment growth rate $(\mathrm{g})$ prior to the observation period. However, the choice of depreciation and growth rate is not obvious. Different approaches have been used to estimate the depreciation rate of $\mathrm{R} \& \mathrm{D}$, and while the intangible assets are typically found to depreciate faster than the tangible assets, the estimates for example for $R \& D$ depreciation can vary from 0 to $40 \%$ (Hall 2005). Furthermore, Awano et al. 2010 find that the benefit lives of other types of intangibles are shorter than the benefit life of $R \& D$. The recent 
literature has typically assumed a depreciation rate of $15 \%$ for R\&D (Hall et al. 2005; Hall et al. 2007), and we will follow this convention. For organizational capital, we assume a depreciation rate of $20 \%$, except for the service industry, where the depreciation rate is set to $25 \%$ because firms in service industry are more intensive in branding and other marketing investments that have been shown to depreciate faster (Awano et al. 2010; Corrado et al. 2005; Görzig et al. 2010). The prior growth rate (g) is assumed to be $8 \%$, which follows the literature on the estimation of initial R\&D stocks. However, it should be noted that the main results are not sensitive to small changes in the assumed growth and depreciation rates.

After the initial values are calculated, the organizational capital stock can be formed. The organizational capital stock is formed as follows:

$$
O C_{i t}^{\text {stock }}=(1-\delta) \times O C_{i, t-1}^{\text {stock }}+O C_{i t}^{\text {invest }}
$$

The companies in the Helsinki stock exchange have increased their business activities abroad during the observation period, but the organizational capital estimates are formed on the basis of Finnish employer-employee data. Hence, the organizational capital estimates do not cover similar offshore investments. However, it is not clear how the offshoring of business activities should affect the management and marketing personnel in the home country. There is evidence (Becker et al. 2009; Head and Ries 2002) that the offshoring of business activities may actually increase the skill intensity of work in the home country, particularly if some activities are offshored to low-income countries. In any case, it appears likely that a major share of organizational investments is performed at the headquarters and 
is therefore included in our estimate and the offshore investments are only adding noise to our estimate.

The firm's R\&D capital stock cannot be directly obtained from the firm's balance sheet but the income statements often include annual $R \& D$ expenses. These expenses are capitalized to compute the $R \& D$ stock. Counting the $R \& D$ stock using equation (7) requires that the starting value of the $R \& D$ stock is estimated in the same way as the starting value of the organizational capital stock (5). The initial value is counted using the R\&D expenditure in the first year and assuming that the investments have grown $8 \%$ annually (Sandner and Block 2011). The depreciation rate is set to $15 \%$ to allow an easy comparison to earlier studies, although small changes in the $\mathrm{R} \& \mathrm{D}$ depreciation or growth rate do not alter the main results significantly.

$$
R \& D_{i t}^{\text {stock }}=(1-\delta) \times R \& D_{i, t-1}^{\text {stock }}+R \& D_{i t}^{\text {invest }}
$$

To allow the calculation of R\&D stock, the short gaps in the R\&D expenditure histories are treated with interpolation when the gaps are not longer than 3 years. No other corrections are made.

The EPO patent data start at 1978 . However, the last 18 months are incomplete because the European Patent Office publishes the applications with some time lag. Furthermore, the use of patent citations as quality indicator limits the available time period. In this study, the forward citations are counted from 3 years after the patent application is published. Observing citations over a longer time period would improve the accuracy of the quality control but only at the cost of a smaller sample. 
Some patents have several applicants, which is considered by applying fractional counting to the data. The economic value is assumed to be uniformly distributed, meaning that if a patent has two applicants, one half of the patent is allocated to each applicant. If there are three applicants, each is allocated one third of the patent, and so on.

The initial value of the patent stock does not need to be estimated because the patent data start from 1978, and the forming of the patent stock is simple once we know the depreciation rate. The previous literature uses the same depreciation rate for both $R \& D$ and patents, and the same approach is adopted here. The patent stock is formed according to the declining balance formula with a depreciation rate of $15 \%$. The patent flow indicates the number of patent applications filed by the firm during year $\mathrm{t}$.

$$
\operatorname{PAT}_{i t}^{\text {stock }}=(1-\delta) \times \mathrm{PAT}_{i, t-1}^{\text {stock }}+\mathrm{PAT}_{i t}^{\text {flow }}
$$

Using the patent stock as a quality indicator for $R \& D$ is not unproblematic because patents are not the only way to utilize inventions, and the value distribution of patents is very skewed (Harhoff et al. 2003). Some patents are highly valuable, whereas others have no commercial application at all. Therefore, it is important to use some indicator of a patent's value. These indicators include forward and backward citations, patent renewals, patent family size, opposition (Harhoff et al. 2003; van Zeebroeck 2011), and even patent filing strategies (van Zeebroeck and Van Pottelsberghe de la Potterie 2011). All these indicators could be used as a control for the patent value, but here we will use the forward citations, which have been found to be a significant factor explaining the firms' market value (Hall et al. 2005; Hall et al. 2007). 
After the publication of a patent application, this patent application may be referenced by other patent applicants if the later invention is based on or related to the earlier invention. Moreover, the patent office conducts a search during the patent-granting procedure and may add relevant citations to the application. Consequently, if a patent receives many citations, it is likely that the underlying invention is important and of high quality. Therefore, citations can be seen as an indicator of patent value. Counting the number of citations to a firm's patents tells us about the quality and economic value of a firm's knowledge stock (Hall et al. 2005; Harhoff et al. 1999; Trajtenberg 1990).

We will assume that the value of the patent when it is applied is proxied by the number of citations it will receive. The value will then depreciate over time. The citations emerge over a long time period which can stretch to decades in some cases (Hall et al. 2005; Hall et al. 2007). Computing a complete citation stock for all the patents in this study is not possible. Alternative approaches are to use methods to correct for the truncation of the data or to use the number of citations received within a shorter time period. Here, we will use citations received within 3 years of publication because this time frame allows us to use recent data and is long enough to observe a notable amount of citations (Marco 2007; Metha et al. 2010). Another difficulty with the citations is that the patents may be applied in several countries, which leads to several publications, which may be cited in subsequent applications. This problem can be solved by using information about patent families. We can consider the citations that the patent receives globally, in Europe, or nationally, or we can consider all the citations that the same patent family receives. Here, we will consider all citations, which the patent application filed at the European Patent Office receives either as 
a European (EP) or an international (WO) patent publication. ${ }^{2}$ The citation stock is formed in the same way as the patent stock (9). The depreciation rate is again set to $15 \%$. The citation flow is the number of citations that the firm's patent applications filed in year $\mathrm{t}$ will receive within 3 years after publication of the patent applications.

$$
\mathrm{CIT}_{i t}^{\text {stock }}=(1-\delta) \times \mathrm{CIT}_{i, t-1}^{\text {stock }}+\mathrm{CIT}_{i t}^{\text {flow }}
$$

In the market value estimation, the intangible capital stocks are used as ratios. R\&D and OC assets are divided by the book value of a firm's total assets. The patent stock is divided by the accumulated R\&D stock and the citation stock is divided by the patent stock because the ratios are used as a quality measure for the $R \& D$ and patent stock, respectively. The citation stock includes also self-citations, which come from a patent application filed by the same company or its subsidiary. Previous studies (Bessen 2008; Hall et al. 2005) have found that self-citations are even more valuable than other citations, particularly for small firms, and therefore self-citations do not need to be excluded.

\subsection{Descriptive statistics}

The market value and balance sheet data consist of 122 listed firms in the Helsinki stock exchange at the end of 2011. 90 of those firms have reported R\&D investments after 1995. For 71 firms, we observe both the firm-reported R\&D and the OC stock, which gives 519 firm-year observations for the years $1995-2008 .^{3}$ The data end in 2008 because we need

\footnotetext{
${ }^{2}$ Patent applications filed at the European Patent Office may also be filed internationally under the Patent Cooperation Treaty (PCT). Later patent applications may cite either of these publications.

${ }^{3}$ For the rest of the firms, the employer-employee data could not be linked reliably. The exact list of firms included in the sample can be found in Appendix 1.
} 
time to observe the forward citations. The sample firms cover over $84 \%$ of the total market capitalization of the Helsinki stock exchange in 2008. Thus, the sample provides a comprehensive picture of the largest Finnish firms.

Table 1 presents some descriptive statistics of the key variables in the final data. Market value, turnover, and other financial figures have been deflated to real 2000 prices using the GDP deflator and are expressed in millions of euros. The average real market value of the sample firms is 3.4 billion Euros. The R\&D assets are on average $21 \%$ of the total assets. The firms' investments in organizational assets are considerably lower than their investments in R\&D. The organizational assets are on average $2.4 \%$ of the total assets, but there is much variation. The variation is also high for the patent and citation variables. For $15 \%$ of the observations, there are no patent applications, whereas the largest patent stock includes over 4000 patents and the largest citation stock includes over 5000 citations. The observations with no patent applications are indicated with a dummy variable, and the ratio of citation stock to patent stock is recorded as zero. The descriptive statistics for the ratio of citations to patents are computed conditional on a non-zero patent stock.

Table 2 reports the correlations between the main variables. The statistically significant correlations are shown with asterisks. The intangible assets are positively correlated with Tobin's q, although the correlation with the patents-R\&D ratio is not significant. OC and $R \& D$ intensities are negatively correlated with the total assets. This result shows that the smaller listed firms invest relatively more in intangibles. The inverse relation between intangible capital and firm size holds also for the whole LEED data, where all firms with a turnover above 1.5 million euros are included (in $2000 €$ ). 
Table 1. Descriptive statistics

\begin{tabular}{lccccc}
\hline Variable & Mean & SD & Min & Median & Max \\
\hline Market capitalization & 3255.8 & 16651.2 & 0.645 & 343.3 & 222980.6 \\
Tobins's q & 1.279 & 1.159 & 0.305 & 0.937 & 14.8 \\
Total assets & 2511.3 & 4879.3 & 5.940 & 442.5 & 33640.5 \\
R\&D stock & 324.4 & 1623.0 & 0 & 51.3 & 18085.4 \\
R\&D stock/Assets & 0.210 & 0.348 & 0 & 0.094 & 4.372 \\
Patent stock & 110.8 & 533.9 & 0 & 9.602 & 4758.5 \\
Patent stock/Assets & 0.052 & 0.107 & 0 & 0.012 & 0.695 \\
Patent stock/R\&D stock & 0.267 & 0.318 & 0 & 0.159 & 2.085 \\
Citation stock & 127.1 & 679.1 & 0 & 5.397 & 5352.1 \\
Citation stock/Patent stock & 0.607 & 0.492 & 0 & 0.530 & 3.398 \\
OC stock & 20.745 & 38.616 & 0 & 6.259 & 318.8 \\
OC stock/Assets & 0.028 & 0.042 & 0 & 0.014 & 0.383 \\
No R\&D (dummy) & 0.029 & 0.168 & 0 & 0 & 1 \\
No patent (dummy) & 0.152 & 0.360 & 0 & 0 & 1 \\
\hline Notes. 519 obs. Financial variables are in millions of Euros, in year 2000 real prices. Patent stock/R\&D \\
stock is reported as patents per million Euros in R\&D stock & & &
\end{tabular}

Table 2. Correlation matrix

\begin{tabular}{lccccc}
\hline & 1. & 2. & 3. & 4. & 5. \\
\hline 1. Tobin's q & & & & & \\
2. Total assets & $0.126^{*}$ & & & & \\
3. R\&D stock/assets & $0.218^{*}$ & $-0.120^{*}$ & & & \\
4. Patent stock/R\&D stock & 0.086 & -0.017 & -0.029 & & \\
5. Citation stock/Patent stock & $0.200^{*}$ & $0.221^{*}$ & 0.058 & $0.196^{*}$ & \\
6. OC stock/Assets & $0.153^{*}$ & $-0.240^{*}$ & $0.275^{*}$ & -0.048 & $-0.142^{*}$ \\
\hline
\end{tabular}

Notes. 519 obs. * $\mathrm{p}<0.05$

Table 3 compares the firm characteristics of $R \& D$ reporters to those firms that do not report their R\&D expenditures but for whom we can still compute the organizational capital stock. The table shows that while concentrating on firms that report $R \& D$ expenditure, we are excluding some of the smaller firms in the stock exchange. The firms that report R\&D expenditures are typically manufacturing or software firms. The firms who do not report $R \& D$ are often engaged in the service, trade, finance, or transportation sector. The firms 
that do not report $R \& D$ have been growing faster than the sample firms, and despite reporting no R\&D, over $40 \%$ of these firms have filed patent applications. Patents indicate that they are indeed active in $\mathrm{R} \& \mathrm{D}$, although they do not report their research expenditures. Furthermore, these firms are slightly more intensive in organizational capital than $R \& D$ reporters.

Table 3. Firm characteristics for R\&D reporters and others

\begin{tabular}{|c|c|c|c|c|}
\hline \multirow[b]{2}{*}{ Variable } & \multicolumn{2}{|c|}{ Reporting R\&D } & \multicolumn{2}{|c|}{ Not reporting $\mathrm{R} \& \mathrm{D}$} \\
\hline & Mean & SD & Mean & SD \\
\hline Market capitalization & 3255.8 & 16651.2 & 384.5 & 1084.0 \\
\hline Tobins's q & 1.279 & 1.159 & 1.352 & 2.955 \\
\hline Total assets & 2511.3 & 4879.3 & 1189.1 & 4740.6 \\
\hline Sales & 2486.6 & 5292.8 & 601.1 & 1350.9 \\
\hline Sales growth & 0.057 & 0.206 & 0.123 & 0.345 \\
\hline Debt & 682.3 & 1350.3 & 176.2 & 845.5 \\
\hline Debt leverage & 0.257 & 0.165 & 0.220 & 0.168 \\
\hline Investments / Assets & 0.012 & 0.220 & 0.062 & 0.207 \\
\hline Patent stock & 110.8 & 533.9 & 1.349 & 6.116 \\
\hline Patent stock/Assets & 0.052 & 0.107 & 0.017 & 0.059 \\
\hline Citation stock & 127.1 & 679.1 & 0.780 & 3.835 \\
\hline Citation stock/Patent stock & 0.607 & 0.492 & 0.782 & 2.039 \\
\hline OC stock & 20.745 & 38.616 & 11.322 & 20.429 \\
\hline OC stock/Assets & 0.028 & 0.042 & 0.037 & 0.042 \\
\hline No patent (dummy) & 0.152 & 0.360 & 0.576 & 0.495 \\
\hline
\end{tabular}

Notes. Reporting R\&D group includes 519 observation for which we observe organizational and R\&D investments. Not reporting R\&D group includes 401 observations for which we observe organizational but not $R \& D$ investments.

Table 4 below presents the industry classification and some summary information for the industries. Because we concentrate only on the firms that report $R \& D$ expenditures, some industries are missing or are thinly presented in our sample. Machinery, electronics, and software are the biggest industry categories in our sample. There are clear differences in the intangible capital intensities and Tobin's q across industries. On average, Tobin's q is the highest in electronics, manufacturing of controlling and other instruments, and software 
firms. Those firms have also an above-average R\&D intensity. Tobin's $q$ is the lowest in food and paper industries, which are also less intensive in intangible investments. The organizational capital intensity is by far the highest in the manufacturing of controlling and other instruments industry, while the lowest intensity is found in the paper industry, which is very intensive in tangible capital. Otherwise, organizational capital is quite evenly distributed across industries. 
Table 4. Industry characteristics

\begin{tabular}{|c|c|c|c|c|c|c|c|c|}
\hline Industry & Obs & Percent & Tobin's q & $\begin{array}{r}\text { Total } \\
\text { assets }\end{array}$ & $\begin{array}{l}\text { R\&D stock/ } \\
\text { Total assets }\end{array}$ & $\begin{array}{c}\text { OC stock/ } \\
\text { Total assets }\end{array}$ & $\begin{array}{c}\text { Patent stock / } \\
\text { R\&D stock }\end{array}$ & $\begin{array}{c}\text { Citation stock / } \\
\text { Patent stock }\end{array}$ \\
\hline Food and kindred products & 42 & 8.09 & 0.739 & 409.400 & 0.075 & 0.018 & 0.114 & 0.962 \\
\hline Chemicals & 32 & 6.17 & 1.221 & 1190.148 & 0.244 & 0.039 & 0.595 & 0.543 \\
\hline Paper and allied products & 45 & 8.67 & 0.738 & 10307.930 & 0.025 & 0.005 & 0.204 & 0.658 \\
\hline Metal industries & 53 & 10.21 & 0.964 & 2052.317 & 0.070 & 0.012 & 0.273 & 0.363 \\
\hline Machinery and computer equipment & 85 & 16.38 & 1.185 & 1352.198 & 0.145 & 0.027 & 0.371 & 0.432 \\
\hline Measuring, analyzing, and controlling instruments & 21 & 4.05 & 1.804 & 109.913 & 0.560 & 0.145 & 0.246 & 0.484 \\
\hline Rubber and miscellaneous plastic products & 28 & 5.39 & 1.458 & 723.008 & 0.103 & 0.013 & 0.400 & 0.542 \\
\hline Transportation, communications \& utilities & 22 & 4.24 & 1.153 & 8365.156 & 0.029 & 0.011 & 0.433 & 0.690 \\
\hline Software & 54 & 10.40 & 1.778 & 134.307 & 0.700 & 0.054 & 0.231 & 0.738 \\
\hline Trade and services & 17 & 3.28 & 0.782 & 847.062 & 0.032 & 0.026 & 0.070 & 0.344 \\
\hline Other industries & 66 & 12.72 & 1.216 & 1080.791 & 0.081 & 0.025 & 0.156 & 0.744 \\
\hline Total & 519 & 100 & 1.279 & 2511.267 & 0.210 & 0.028 & 0.267 & 0.607 \\
\hline
\end{tabular}

Notes. Financial variables are in millions of Euros, in year 2000 real prices. Patent stock/ R\&D stock is reported as patents per million Euros in R\&D stock 


\section{Results}

This section presents the results from the estimation of the market value equation. The dependent variable is the same, log of Tobin's q, in all models. Table 5 presents the results from the basic non-linear least squares (NLS) models. Because of the model's non-linearity and the differing units of measurement, the interpretation of the coefficients is not straightforward, and it is more informative to examine the mean elasticities. These elasticities are reported at the end of Table 5. The panel estimation, which also considers the unobserved firm-specific effects, is presented in Table 6 together with the ordinary least squares regression results.

The first column in Table 5 shows the results from the baseline model (model 0) excluding all the intangibles. Model 1 in Table 5 is estimated with knowledge capital and includes $R \& D$, patent, and citation variables as well as dummies for years and industries. The model is estimated with the sample for which the organizational capital can also be calculated. Specification 2 also includes the organizational capital. The third model excludes the patent variables and includes only $R \& D$ and organizational capital.

The results in the second column of Table 5 show that the knowledge assets can explain a significant part of the variation in Tobin's q. The adjusted R-squared increases from 0.288 to 0.328 when the knowledge assets are included. The companies with higher intangible capital intensities have a higher market valuation. The R\&D stock and patent citations are positively and significantly related to the market value of firms. The ratio of patent stock to $R \& D$ stock has an insignificant yet positive coefficient. Model 1 in Table 5 is comparable to the models presented in the previous literature (Hall et al. 2005; Hall et al. 2007). Although our sample contains smaller firms on average compared to previous 
studies and the industry composition in the Helsinki stock exchange is somewhat different, the results from the first model are in line with earlier results. The elasticity of Tobin's q with respect to the patent intensity is not significant, which is also in line with previous studies that have found that the cited patents are more strongly related to the market value. However, when model 1 is estimated with a larger sample and over a longer time period, 1988-2008 (model 1B. in Table 7), we note that also the patent variable becomes statistically significant.

Specifications 2 and 3 in Table 5 also include the organizational capital intensity variable. The results show that organizational capital is positively related to higher Tobin's $\mathrm{q}$, and the elasticity of Tobin's $\mathrm{q}$ with respect to organizational capital intensity is approximately $11 \%$. Based on these results, organizational capital has a larger effect on firms' market value than R\&D and patents. Moreover, the inclusion of organizational capital raises the elasticities of $\mathrm{R} \& \mathrm{D}$ and patents by almost $2 \%$, while the citation elasticity is now lower. This effect remains even when we extend the model with more control variables (see columns 3 and 4 in Table 7). The omission of organizational capital would cause us to significantly underestimate the importance of $R \& D$ and patents and overestimate the impact of patent citations. Furthermore, the inclusion of organizational capital increases the adjusted R-squared from 0.328 to 0.360 . 
Table 5. Results from NLS regression

\begin{tabular}{|c|c|c|c|c|}
\hline $\begin{array}{c}\text { Dependent variable: } \\
\log \text { Tobin's q } \\
\end{array}$ & 0. & 1. & 2. & 3. \\
\hline Constant & $\begin{array}{c}-0.768^{* * * *} \\
(0.361)\end{array}$ & $\begin{array}{l}-0.534 \\
(0.381)\end{array}$ & $\begin{array}{c}-1.374 * * * * \\
(0.386)\end{array}$ & $\begin{array}{c}-1.807 * * * \\
(0.392)\end{array}$ \\
\hline log Total Assets & $\begin{array}{c}0.025 \\
(0.017)\end{array}$ & $\begin{array}{c}0.006 \\
(0.017)\end{array}$ & $\begin{array}{c}0.040 * * \\
(0.017)\end{array}$ & $\begin{array}{c}0.068 * * * \\
(0.018)\end{array}$ \\
\hline R\&D/Assets & & $\begin{array}{l}0.227 * \\
(0.123)\end{array}$ & $\begin{array}{c}0.420 * * \\
(0.165)\end{array}$ & $\begin{array}{c}0.417 \text { *** } \\
(0.144)\end{array}$ \\
\hline Patents/R\&D & & $\begin{array}{c}0.167 \\
(0.109)\end{array}$ & $\begin{array}{c}0.288^{* *} \\
(0.126)\end{array}$ & \\
\hline Citations/Patents & & $\begin{array}{c}0.280 * * * \\
(0.107)\end{array}$ & $\begin{array}{c}0.248 * * \\
(0.103)\end{array}$ & \\
\hline OC/Assets & & & $\begin{array}{c}7.376 * * * \\
(2.225)\end{array}$ & $\begin{array}{c}6.030 * * * \\
(1.871)\end{array}$ \\
\hline No R\&D & & $\begin{array}{c}0.322 * * \\
(0.156)\end{array}$ & $\begin{array}{l}0.284 * \\
(0.168)\end{array}$ & $\begin{array}{c}0.222 \\
(0.165)\end{array}$ \\
\hline No patent & & $\begin{array}{c}0.014 \\
(0.103)\end{array}$ & $\begin{array}{l}-0.033 \\
(0.101)\end{array}$ & \\
\hline Adj. R-squared & 0.288 & 0.328 & 0.360 & 0.327 \\
\hline Observations & 519 & 519 & 519 & 519 \\
\hline \multicolumn{5}{|l|}{ Elasticities } \\
\hline R\&D/Assets & & $\begin{array}{c}0.036^{* *} \\
(0,018)\end{array}$ & $\begin{array}{c}0.053^{* * * *} \\
(0.018)\end{array}$ & $\begin{array}{c}0.063^{* * * *} \\
(0.018)\end{array}$ \\
\hline Patents/R\&D & & $\begin{array}{c}0.033 \\
(0.021)\end{array}$ & $\begin{array}{c}0.050^{* *} \\
(0.020)\end{array}$ & \\
\hline Citations/Patents & & $\begin{array}{c}0.107^{* * * *} \\
(0.034)\end{array}$ & $\begin{array}{c}0.087 \text { *** } \\
(0.031)\end{array}$ & \\
\hline OC/Assets & & & $\begin{array}{c}0.120 * * * \\
(0.027)\end{array}$ & $\begin{array}{c}0.117 * * * \\
(0.028)\end{array}$ \\
\hline
\end{tabular}

Notes. All equations include full set of year and industry dummies. Robust standard errors in parenthesis. Reference year: 2008. Reference industry class: Other industries. $* \mathrm{p}<0.10, * * \mathrm{p}<0.05, * * * \mathrm{p}<0.01$

Table 6 below presents the results from the ordinary least squares estimation and panel models. Models 1-3, which were estimated with NLS, are now estimated with OLS, fixed effect, and random effect estimation. Of the two panel models, the random effect model is consistent and efficient if the firm-specific effects are uncorrelated with other right-hand 
side variables. To test this assumption, we run the Hausman specification test (Hausman 1978). The Hausman test results show that the differences between fixed effect and random effect models are significant, and hence we should reject the random effect model in favor of the fixed effect model. However, as noted earlier, the intangibles are strategic investments that are expected to change only slowly over time and that are thus heavily correlated with the firm fixed effects. Particularly the organizational practices are usually very persistent. In fixed effect estimation, the organizational capital intensity is likely to be highly correlated with its individual effects, which may explain the result.

OLS results in Table 6 show highly significant coefficients for every intangible asset type. After controlling for firm-specific effects, $R \& D$, and citation intensities remain significant both in fixed and random effect models, whereas organizational capital, due to its persistency, is significant only in the random effect model. The patent intensity variable is not significant in any of the models that consider firm-specific effects.

To check the robustness of the results, models 1 and 3 are estimated with a larger sample. The larger sample can be obtained by extending the time period when we drop either the patent variables or the organizational capital from the model. Models 1B and 3B in Table 7 present the results from these models. Model 1B is estimated for knowledge capital for the years $1988-2008$, and model 3B is estimated for R\&D and organizational capital for the years 1995-2011. The results again show a positive and significant relationship between intangible capital intensities and market value. The relationship even appears slightly stronger for R\&D and organizational capital. 
Table 6. Results from the panel models

\begin{tabular}{|c|c|c|c|c|c|c|c|c|c|}
\hline \multirow[b]{2}{*}{$\begin{array}{c}\text { Dependent variable: } \\
\text { log Tobin's q } \\
\end{array}$} & \multicolumn{3}{|c|}{ OLS* } & \multicolumn{3}{|c|}{ Fixed Effects $^{+}$} & \multicolumn{3}{|c|}{ Random Effects $^{+}$} \\
\hline & 1. & 2. & 3. & 1. & 2. & 3. & 1. & 2. & 3. \\
\hline Constant & $\begin{array}{l}-0.121 \\
(0.335)\end{array}$ & $\begin{array}{c}-0.717 * * \\
(0.362)\end{array}$ & $\begin{array}{c}-0.844 * * \\
(0.350)\end{array}$ & $\begin{array}{l}-0.501 \\
(1.211)\end{array}$ & $\begin{array}{l}-1.193 \\
(1.370)\end{array}$ & $\begin{array}{l}-1.165 \\
(1.333)\end{array}$ & $\begin{array}{l}0.128 \\
(0.574)\end{array}$ & $\begin{array}{l}-0.516 \\
(0.617)\end{array}$ & $\begin{array}{l}-0.359 \\
(0.597)\end{array}$ \\
\hline log Total Assets & $\begin{array}{l}-0.019 \\
(0.015)\end{array}$ & $\begin{array}{c}0.007 \\
(0.017)\end{array}$ & $\begin{array}{l}0.021 \\
(0.017)\end{array}$ & $\begin{array}{c}0.001 \\
(0.059)\end{array}$ & $\begin{array}{c}0.032 \\
(0.066)\end{array}$ & $\begin{array}{c}0.039 \\
(0.065)\end{array}$ & $\begin{array}{l}-0.028 \\
(0.028)\end{array}$ & $\begin{array}{c}0.000 \\
(0.030)\end{array}$ & $\begin{array}{l}-0.001 \\
(0.029)\end{array}$ \\
\hline R\&D/Assets & $\begin{array}{c}0.422 * * * \\
(0.097)\end{array}$ & $\begin{array}{c}0.392 * * * \\
(0.084)\end{array}$ & $\begin{array}{c}0.435 * * * \\
(0.095)\end{array}$ & $\begin{array}{c}0.208 * * \\
(0.098)\end{array}$ & $\begin{array}{l}0.207 * * \\
(0.098)\end{array}$ & $\begin{array}{l}0.181 * \\
(0.098)\end{array}$ & $\begin{array}{c}0.230 * * * \\
(0.084)\end{array}$ & $\begin{array}{c}0.218^{* * * *} \\
(0.084)\end{array}$ & $\begin{array}{l}0.206^{* *} \\
(0.084)\end{array}$ \\
\hline Patents/R\&D & $\begin{array}{c}0.247 * * * \\
(0.072)\end{array}$ & $\begin{array}{c}0.262 * * * \\
(0.071)\end{array}$ & & $\begin{array}{c}0.090 \\
(0.154)\end{array}$ & $\begin{array}{c}0.111 \\
(0.156)\end{array}$ & & $\begin{array}{c}0.047 \\
(0.113)\end{array}$ & $\begin{array}{c}0.066 \\
(0.112)\end{array}$ & \\
\hline Citations/Patents & $\begin{array}{l}0.172 * * \\
(0.075)\end{array}$ & $\begin{array}{l}0.181 * * \\
(0.072)\end{array}$ & & $\begin{array}{c}0.229 * * * \\
(0.071)\end{array}$ & $\begin{array}{c}0.227 * * * \\
(0.071)\end{array}$ & & $\begin{array}{c}0.212 * * * \\
(0.064)\end{array}$ & $\begin{array}{c}0.210^{* * * *} \\
(0.063)\end{array}$ & \\
\hline OC/Assets & & $\begin{array}{c}2.691 * * * \\
(0.749)\end{array}$ & $\begin{array}{c}2.573 * * * \\
(0.737)\end{array}$ & & $\begin{array}{c}1.662 \\
(1.538)\end{array}$ & $\begin{array}{c}1.773 \\
(1.546)\end{array}$ & & $\begin{array}{l}2.540 * * \\
(0.995)\end{array}$ & $\begin{array}{l}2.495^{* *} \\
(1.005)\end{array}$ \\
\hline No $R \& D$ & $\begin{array}{l}0.332 * \\
(0.184)\end{array}$ & $\begin{array}{c}0.287 \\
(0.182)\end{array}$ & $\begin{array}{c}0.221 \\
(0.186)\end{array}$ & $\begin{array}{l}0.477 * \\
(0.259)\end{array}$ & $\begin{array}{l}0.481^{*} \\
(0.259)\end{array}$ & $\begin{array}{c}0.516 * * * \\
(0.189)\end{array}$ & $\begin{array}{l}0.245 \\
(0.170)\end{array}$ & $\begin{array}{c}0.203 \\
(0.168)\end{array}$ & $\begin{array}{c}0.227 \\
(0.147)\end{array}$ \\
\hline No patent & $\begin{array}{c}0.034 \\
(0.090)\end{array}$ & $\begin{array}{c}0.070 \\
(0.090)\end{array}$ & & $\begin{array}{c}0.333 * * * \\
(0.110)\end{array}$ & $\begin{array}{c}0.332 * * * \\
(0.110)\end{array}$ & & $\begin{array}{l}0.225 * * \\
(0.096)\end{array}$ & $\begin{array}{l}0.229 * * \\
(0.095)\end{array}$ & \\
\hline Adj. R-squared & 0.184 & 0.220 & 0.181 & 0.149 & 0.172 & 0.142 & 0.177 & 0.215 & 0.188 \\
\hline Observations & 519 & 519 & 519 & 519 & 519 & 519 & 519 & 519 & 519 \\
\hline $\begin{array}{c}\text { Hausman test } \\
\text { p-value }\end{array}$ & & & & $\begin{array}{l}41.87 \\
(0.002)\end{array}$ & $\begin{array}{l}41.82 \\
(0.002)\end{array}$ & $\begin{array}{c}36.95 \\
(0.003)\end{array}$ & & & \\
\hline
\end{tabular}


Table 7. Results from regressions with larger sample and more control variables

\begin{tabular}{|c|c|c|c|c|}
\hline $\begin{array}{c}\text { Dependent variable: } \\
\text { log Tobin's q } \\
\end{array}$ & $1 B$. & 3B. & $1 \mathrm{C}$. & $2 \mathrm{C}$. \\
\hline Constant & $\begin{array}{c}0.152 \\
(0.372)\end{array}$ & $\begin{array}{c}-1.706^{* * * *} \\
(0.329)\end{array}$ & $\begin{array}{c}0.067 \\
(0.396)\end{array}$ & $\begin{array}{l}-0.744^{*} \\
(0.395)\end{array}$ \\
\hline log Total Assets & $\begin{array}{c}-0.030^{*} \\
(0.017)\end{array}$ & $\begin{array}{c}0.062 * * * \\
(0.015)\end{array}$ & $\begin{array}{l}-0.014 \\
(0.016)\end{array}$ & $\begin{array}{c}0.017 \\
(0.016)\end{array}$ \\
\hline R\&D/Assets & $\begin{array}{c}0.537 * * * \\
(0.125)\end{array}$ & $\begin{array}{c}0.405^{* * * *} \\
(0.105)\end{array}$ & $\begin{array}{l}0.371^{*} \\
(0.209)\end{array}$ & $\begin{array}{c}0.615^{* *} \\
(0.279)\end{array}$ \\
\hline Patents/R\&D & $\begin{array}{c}0.210 * * \\
(0.087)\end{array}$ & & $\begin{array}{c}0.143 \\
(0.098)\end{array}$ & $\begin{array}{c}0.263 * * \\
(0.118)\end{array}$ \\
\hline Citations/Patents & $\begin{array}{r}0.207^{* *} \\
(0.093)\end{array}$ & & $\begin{array}{c}0.298 * * * \\
(0.106)\end{array}$ & $\begin{array}{c}0.284 * * * \\
(0.106)\end{array}$ \\
\hline OC/Assets & & $\begin{array}{c}6.345^{* * * *} \\
(1.396)\end{array}$ & & $\begin{array}{c}6.808 * * * \\
(2.078)\end{array}$ \\
\hline No $R \& D$ & $\begin{array}{l}-0.002 \\
(0.154)\end{array}$ & $\begin{array}{c}0.220 \\
(0.151)\end{array}$ & $\begin{array}{c}0.332^{* *} \\
(0.155)\end{array}$ & $\begin{array}{l}0.298^{*} \\
(0.165)\end{array}$ \\
\hline No patent & $\begin{array}{l}0.019 \\
(0.087)\end{array}$ & & $\begin{array}{c}0.025 \\
(0.101)\end{array}$ & $\begin{array}{l}-0.010 \\
(0.098)\end{array}$ \\
\hline Debt leverage & & & $\begin{array}{c}-0.667 * * * \\
(0.175)\end{array}$ & $\begin{array}{c}-0.550 * * * \\
(0.176)\end{array}$ \\
\hline Sales growth & & & $\begin{array}{c}0.481 * * * \\
(0.173)\end{array}$ & $\begin{array}{c}0.472 * * * \\
(0.174)\end{array}$ \\
\hline Investments / Total Assets & & & $\begin{array}{c}0.056 \\
(0.199) \\
\end{array}$ & $\begin{array}{c}0.137 \\
(0.199) \\
\end{array}$ \\
\hline $\begin{array}{l}\text { Adj. R-squared } \\
\text { Observations }\end{array}$ & $\begin{array}{c}0.373 \\
717\end{array}$ & $\begin{array}{c}0.317 \\
719\end{array}$ & $\begin{array}{c}0.396 \\
516\end{array}$ & $\begin{array}{c}0.426 \\
516\end{array}$ \\
\hline \multicolumn{5}{|l|}{ Elasticities } \\
\hline R\&D/Assets & $\begin{array}{c}0.088 * * * \\
(0.016)\end{array}$ & $\begin{array}{c}0.064 * * * \\
(0.014)\end{array}$ & $\begin{array}{l}0.054^{* * *} \\
(0.026)\end{array}$ & $\begin{array}{c}0.072 * * * \\
(0.026)\end{array}$ \\
\hline Patents/R\&D & $\begin{array}{c}0.034 * * * \\
(0.013)\end{array}$ & & $\begin{array}{c}0.027 \\
(0.017)\end{array}$ & $\begin{array}{l}0.044 * * \\
(0.018)\end{array}$ \\
\hline Citations/Patents & $\begin{array}{c}0.073 * * * \\
(0.028)\end{array}$ & & $\begin{array}{c}0.109 * * * \\
(0.032)\end{array}$ & $\begin{array}{c}0.095 * * * \\
(0.030)\end{array}$ \\
\hline OC/Assets & & $\begin{array}{c}0.123 * * * \\
(0.021)\end{array}$ & & $\begin{array}{c}0.107 * * * \\
(0.024)\end{array}$ \\
\hline
\end{tabular}

Notes. All equations include full set of year and industry dummies. Robust standard errors in parenthesis.

Reference year: 2008. Reference industry class: Other industries. ${ }^{*} \mathrm{p}<0.10,{ }^{* *} \mathrm{p}<0.05,{ }^{* * *} \mathrm{p}<0.01$ 
The last two columns in Table 7 show models 1 and 2 extended with additional control variables, which may affect the market value systematically. The control variables include the ratio of net investments to total assets, the growth of sales as a control for future growth prospects, and debt leverage. Adding more control variables does not change the main results, if anything, additional controls strengthen the relationship between the intangibles and the market value.

Further robustness checks were conducted by estimating the model in smaller subsamples. The sample was divided into manufacturing and non-manufacturing companies and into large and small companies based on their sales. The smaller firms are more intensive in $\mathrm{R} \& \mathrm{D}$ and $\mathrm{OC}$ but not in patents. The intangible capital intensity also varies more in the smaller firms than in the larger firms. When the market value model is estimated, the results show that the market value reacts more strongly to the R\&D intensity in small companies but the patent variables do not have significant effects. For the larger firms, both patent citations and R\&D are statistically significant in explaining the market value. The elasticity of Tobin's q with respect to organizational capital is similar both for large and small firms, although it is slightly higher for large firms.

The manufacturing firms are by far the largest group, and the results for them mirror the aggregate results. The variation of intangible capital intensity among the nonmanufacturing firms is large because the software industry is very $R \& D$ intensive, whereas the other firms invest relatively little in $\mathrm{R} \& \mathrm{D}$. For organizational capital, there are no large differences between the manufacturing industry and the other industries, except again for software firms, which invest more in organizational capital. The market value of nonmanufacturing companies is positively related to high $R \& D$ intensity but the patent variables have no or even a slightly negative relation to the market value. The 
organizational capital is a significant factor explaining the market value in every industry, and particularly so in the software and other service firms.

\section{Conclusions}

This study has investigated the relationship between intangible capital and the stock market valuation of Finnish firms using R\&D expenditures, patent applications, and organizational investment data. While the market value of $R \& D$ and patents has been frequently analyzed, organizational assets have been absent from these studies. At the same time, the existing studies that do consider organizational capital (for example Lev and Radhakrishnan (2005), Brynjolfsson et al. (2002), Joshi and Hanssens (2010), and Piekkola (2013)) do not include patent variables in their analysis. In this paper, we complement patent and R\&D expenditure data by using a rich Finnish linked employer-employee dataset to create estimates of firms' organizational assets. We follow the approach presented in Görzig et al. (2010) and estimated firms' organizational investments using the wage costs of managers and marketing personnel.

Our results show that organizational assets, $R \& D$, and patent citations are significantly associated with a higher market value. Including all intangible assets into the market value model raises the adjusted R-squared from 0.288 to 0.360 . The estimates for the elasticity of Tobin's q with respect to organizational capital intensity are in the range of $10-12 \%$, which is somewhat higher than the estimated R\&D elasticity of Tobin's q. Previous studies with US and European data have shown that R\&D assets and patent citations are significant factors explaining the market value of firms. The results obtained in this study confirm these results for the Finnish data with, on average, smaller firms. Financial markets value $R \& D$ assets and patent citations, but the plain patent counts are 
significant in only some of the model specifications. Our estimate of the elasticity of Tobin's $q$ with respect to R\&D intensity varies from $4 \%$ to $9 \%$. The estimated citation elasticity is also quite high, close to $10 \%$ in most model specifications. Moreover, the results indicate that it is important that we do not fail to include the organizational capital in the market value model because the omission of organizational capital would cause us to significantly underestimate the importance of $R \& D$ and patents and overestimate the impact of patent citations.

The results are robust after adding control variables and estimating the model for a longer time period. The panel estimation shows that after considering the unobserved firmspecific effects, the R\&D, citation, and in random effects models also the organizationalcapital intensity can still explain a significant amount of variation in Tobin's q. Our results have shown that investments in management and marketing have a positive relation to the firm's market value, and this relation is even stronger than that of research and development investments 


\section{References}

Awano, G., M. Franklin, J. Haskel and Z. Kastrinaki. 2010. Measuring Investment in Intangible Assets in the UK: Results from a New Survey. Economic \& Labour Market Review 4, no 7: 66-71.

Becker, S., K. Ekholm and M.-A. Muendler. 2009. Offshoring and the Onshore Composition of Tasks and Skills. IAW Discussion Papers 55.

Bessen, J. 2008. The Value of U.S. Patents by Owner and Patent Characteristics. Research Policy 37: 932-45.

Brynjolfsson, E., L.M. Hitt and S. Yang. 2002. Intangible Assets: Computers and Organizational Capital. Brookings Papers on Economic Activity 1: 137-81.

Chan, L.K.C., J. Lakonishok and T. Sougiannis. 2001. The Stock Market Valuation of Research and Development Expenditure. The Journal of Finance 56: 2431-56.

Corrado, C., C. Hulten and D. Sichel. 2005. Measuring Capital and Technology: An Expanded Framework. National Bureau of Economic Research. In Studies in Income and Wealth, eds Corrado, C, Haltiwanger, J and Sichel, D, 11-45. Chicago: University Chicago Press.

Corrado, C., C. Hulten and D. Sichel. 2009. Intangible Capital and U.S. Economic Growth. The Review of Income and Wealth 55, no 3: 661-85.

Czarnitzki, D., B.H. Hall and R. Oriani. 2006. Market Valuation of Us and European Intellectual Property. In The Management of Intellectual Property, eds Bosworth, D and Webster, E, 111-31: Edward Elgar Publishing.

Deng, Y. 2007. Private Value of European Patents. European Economic Review: 1785-812.

EPO. 2011. Patstat - EPO Worldwide Statistical Database, October 2011.

Griliches, Z. 1981. Market Value, R\&D and Patents. Economic Letters 7: 183-87.

Görzig, B., H. Piekkola and R. Riley. 2010. Production of Intangible Investment and Growth: Methodology in Innodrive. Innodrive working paper No. 1.

Hall, B.H. 2000. Innovation and Market Value. In Productivity, Innovation and Economic Performance, eds Barrell, R, Mason, G and O'mahony, M: Cambridge University Press.

Hall, B.H. 2005. Measuring Returns to R\&D: The Depreciation Problem. Annales D'Économie et de Statistique 79/80.

Hall, B.H., A. Jaffe and M. Trajtenberg. 2005. Market Value and Patent Citations. Rand Journal of Economics 36, no 1: 16-38. 
Hall, B.H. and R. Oriani. 2006. Does the Market Value R\&D Investment by European Firms? Evidence from a Panel of Manufacturing Firms in France, Germany, and Italy. International Journal of Industrial Organization 24, no 5: 971-93.

Hall, B.H., G. Thoma and S. Torrisi. 2007. The Market Value of Patents and R\&D: Evidence from European Firms. NBER Working Paper no. 13426.

Harhoff, D., F. Narin, F.M. Scherer and K. Vopel. 1999. Citation Frequency and the Value of Patented Innovation. Review of Economics and Statistics 81, no 3: 511-15.

Harhoff, D., F.M. Scherer and K. Vopel. 2003. Citations, Family Size, Opposition and the Value of Patent Rigths - Evidence from Germany. Research Policy 32, no 8: 134363.

Hausman, J.A. 1978. Specification Tests in Econometrics. Econometrica 46: 1251-72.

Head, K. and J. Ries. 2002. Offshore Production and Skill Upgrading by Japanese Manufacturing Firms. Journal of International Economics 58, no 1: 81-105.

Hulten, C. and X. Hao. 2008. What Is Company Really Worth? Intangible Capital and the "Market to Book Value" Puzzle. NBER Working Paper 14548.

Lev, B. and S. Radhakrishnan. 2003. The Measurement of Firm-Specific Organization Capital. NBER Working Paper 9581.

Lev, B. and S. Radhakrishnan. 2005. The Valuation of Organization Capital. In Measuring Capital in the New Economy Nber Studies in Income and Wealth eds Corrado, C, Haltiwanger, J and Sichel, D, 73-99. Chicago and London: University of Chicago Press.

Levin, R.C., A.K. Klevorick, R.R. Nelson and S.G. Winter. 1987. Appropriating the Returns from Industrial R\&D. Brookings Papers on Economic Activity 3: 783-832.

Marco, A.C. 2007. The Dynamics of Patent Citations. Economics Letters 94, no 2: 290-96.

Megna, P. and M. Klock. 1993. The Impact of Intangible Capital on Tobin's Q in the Semiconductor Industry. The American Economic Review 83, no 2: 265-69.

Metha, A., M. Rysman and T. Simcoe. 2010. Identifying the Age Profile of Patent Citations: New Estimates of Knowledge Diffusion. Journal of Applied Econometrics 25, no 7: 1179-204.

OECD. 2013. OECD Citations Database, January 2013.

Piekkola, H. 2013. Intangible Investment and Market Value. Presented in Finnish Economic Association XXXV Annual Meeting 14.2.2013: Unpublished working paper. 
Sandner, P.G. and J. Block. 2011. The Market Value of R\&D, Patents and Trademarks. Research Policy 40, no 7.

Toivanen, O., P. Stoneman and D. Bosworth. 2002. Innovation and the Market Value of Uk Firms, 1989-1995. Oxford Bulletin of Economics and Statistics 64, no 1: 39-61.

Trajtenberg, M. 1990. A Penny for Your Quotes: Patent Citations and the Value of Innovations. The RAND Journal of Economics 21: 172-87.

van Zeebroeck, N. 2011. The Puzzle of Patent Value Indicators. Economics of Innovation \& New Technology 20, no 1:33-62.

van Zeebroeck, N. and B. Van Pottelsberghe de la Potterie. 2011. Filing Strategies and Patent Value. Economics of Innovation and New Technology 20, no 6: 539-61. 
Appendix 1. Sample firms

\begin{tabular}{|c|c|}
\hline 1. Affecto Oyj & 37. Metsä Board Oyj \\
\hline 2. Ahlstrom Oyj & 38. Metso Oyj \\
\hline 3. Aldata Solution Oyj & 39. Neste Oil Oyj \\
\hline 4. Alma Media Oyj & 40. Nokia Oyj \\
\hline 5. Amer Sports Oyj & 41. Nokian Renkaat Oyj \\
\hline 6. Aspo Oyj & 42. Okmetic Oyj \\
\hline 7. Aspocomp Group Oyj & 43. Olvi Oyj \\
\hline 8. Atria Oyj & 44. Orion Oyj \\
\hline 9. Basware Oyj & 45. Outokumpu Oyj \\
\hline 10. Biohit Oyj & 46. Outotec Oyj \\
\hline 11. Cargotec Oyj & 47. Panostaja Oyj \\
\hline 12. Cencorp Oyj & 48. PKC Group Oyj \\
\hline 13. Componenta Oyj & 49. Ponsse Oyj \\
\hline 14. Comptel Oyj & 50. Raisio Oyj \\
\hline 15. Digia Oyj & 51. Rapala VMC Oyj \\
\hline 16. Dovre Group & 52. Rautaruukki Oyj \\
\hline 17. Elecster Oyj & 53. Raute Oyj \\
\hline 18. Elisa Oyj & 54. Revenio Group Oyj \\
\hline 19. Exel Composites Oyj & 55. Sanoma Oyj \\
\hline 20. Fiskars Oyj & 56. Solteq Oyj \\
\hline 21. Fortum Oyj & 57. SSH Communications Security Oyj \\
\hline 22. F-Secure Oyj & 58. Stonesoft Oyj \\
\hline 23. GeoSentric Oyj & 59. Stora Enso Oyj \\
\hline 24. Glaston Oyj & 60. Suominen Oyj \\
\hline 25. HKScan Oyj & 61. Talentum Oyj \\
\hline 26. Honkarakenne Oyj & 62. Talvivaara Oyj \\
\hline 27. Incap Oyj & 63. Tecnotree Oyj \\
\hline 28. Ixonos Oyj & 64. Teleste Oyj \\
\hline 29. Kemira Oyj & 65. Tieto Oyj \\
\hline 30. Keskisuomalainen Oyj & 66. Tulikivi Oyj \\
\hline 31. Kesla Oyj & 67. UPM-Kymmene Oyj \\
\hline 32. Kone Oyj & 68. Uponor Oyj \\
\hline 33. Konecranes Oyj & 69. Vaisala Oyj \\
\hline 34. Lassila \& Tikanoja Oyj & 70. Wärtsilä Oyj \\
\hline $\begin{array}{l}\text { 35. Lännen Tehtaat Oyj } \\
\text { 36. Martela Oyj }\end{array}$ & 71. YIT Oyj \\
\hline
\end{tabular}




\section{Appendix 2. Estimating the organizational investments}

Corrado et al. (2005) divide intangible assets into three categories: computerized information, scientific and creative property, and economic competencies. In the center of economic competencies is organizational capital which includes the competence of management and human resources, brands and marketing competencies as well as organizational structure.

GPR (2010) describe in detail the method to estimate the own-account production of organizational capital. The authors present both an expenditure-based and a performancebased approach to estimate intangible investments. In this paper, we use the expenditurebased approach. This method assesses the labor input in organizational activities using linked employer-employee data (LEED) and input and output tables to obtain intermediate and capital input in intangible capital production. The LEED data comes from the Confederation of Finnish Industries and covers 8.3 million person-year and over 56 thousand firm-year observations for the years 1995-2008. The data contain detailed information about employees' occupations, education, and wages in the private sector. The occupational classification, which is central for the estimation method, is available for all of the firms' employees.

GPR (2010) count as organizational occupations the following categories: management, marketing, superior positions in financial administration, and in the service sector also the superior jobs in administration. In the LEED data, approximately $6 \%$ of the employees are reported to work in these occupations. Following this methodology, it is assumed that $20 \%$ of organizational workers' time is engaged in the production of intangible capital. There is substantial uncertainty about this assumption but nevertheless it 
is the best estimate suggested by Corrado et al. (2005) and GPR (2010). Based on this assumption, $20 \%$ of organizational workers' wages should be counted as intangible investment. The employee compensation is evaluated based on monthly salaries and the average social security tax over the period.

In difference to Corrado et al., the GPR approach calculates the total production costs of new intangible capital, which requires also the evaluation of the intermediate and capital costs that are related to the intangible capital-related work. These costs consist of conventional inputs needed to produce the services such as electricity or office space. The evaluation of these additional costs is conducted using the cost structure of firms who produce and sell comparable intangible goods in the market. The organizational and marketing activities within firms in all industries are assumed to have the same cost structure as the EU average in the business service sector (Nace 74 "Other business activities"). The cost structure indicates the magnitude by which the wage costs need to be multiplied to account for intermediate and capital costs. An external rate of return of $4 \%$, presenting the market interest rate, is applied to the use of tangible capital. Multiplied with the net capital stock, this calculation yields the interest part of the user costs. Counting these additional costs results in a combined multiplier of $35 \%$ with which the wage costs are multiplied to obtain the investment flows in organizational capital.

This methodology estimates only the own-account production of intangibles, and it remains unclear how these investments are related to the purchased intangibles. GPR (2010) argue that at least based on the UK businesses included in the Annual Business Inquiry, the purchases of intangible goods are complementary to firms' own-account production. The authors report that, while there is some variation across intangible capital categories, for example the purchase of advertising services is positively correlated with 
intra-firm expenditures on marketing across firms in all industries. These findings suggest that the organizational capital estimates provide reasonable indicators of total organizational investments across firms.

\section{Appendix 3. Sample selection model}

The probability of a firm reporting $R \& D$ is explained by the firm's log sales, the industry R\&D intensity (sum of industry $R \& D$ expenditures divided by industry total sales), the firm's capital intensity (total assets divided by sales), and year dummies. 
Table 8. Sample selection model

\begin{tabular}{|c|c|}
\hline Observations & 1542 \\
\hline Number reporting $R \& D$ & 832 \\
\hline Share reporting R\&D & $53.96 \%$ \\
\hline \multicolumn{2}{|l|}{ Probit for reporting R\&D: } \\
\hline log Sales & $\begin{array}{c}0.309^{* * *} \\
(0.020)\end{array}$ \\
\hline Industry $R \& D$ intensity & $\begin{array}{c}22.702 * * * \\
(1.618)\end{array}$ \\
\hline Capital intensity & $\begin{array}{l}0.001 * \\
(0.000)\end{array}$ \\
\hline Pseudo R-squared & 0.240 \\
\hline Observations & 1542 \\
\hline \multicolumn{2}{|l|}{ NLS Regression: } \\
\hline $\begin{array}{c}\text { Dependent variable: } \\
\text { log Tobin's q }\end{array}$ & $1 D$. \\
\hline Constant & $\begin{array}{l}-0.434 \\
(0.700)\end{array}$ \\
\hline log Total Assets & $\begin{array}{l}-0.022 \\
(0.030)\end{array}$ \\
\hline R\&D/Assets & $\begin{array}{c}0.464 * * * \\
(0.139)\end{array}$ \\
\hline Patents/R\&D & $\begin{array}{l}0.200 * * \\
(0.086)\end{array}$ \\
\hline Citations/Patents & $\begin{array}{r}0.202 * * \\
(0.093)\end{array}$ \\
\hline No R\&D & $\begin{array}{l}-0.047 \\
(0.152)\end{array}$ \\
\hline No patent & $\begin{array}{c}0.014 \\
(0.086)\end{array}$ \\
\hline Mill's ratio & $\begin{array}{c}0.070 \\
(0.175)\end{array}$ \\
\hline $\begin{array}{l}\text { Adj. R-squared } \\
\text { Observations }\end{array}$ & $\begin{array}{c}0.370 \\
714\end{array}$ \\
\hline
\end{tabular}

Notes. $* \mathrm{p}<0.10, * * \mathrm{p}<0.05, * * * \mathrm{p}<0.01$

Equation includes a full set of year and industry dummies.

Robust standard errors in parenthesis 